\title{
What is measured by the alcian blue binding to red blood cells?
}

\section{A MUTTI, ${ }^{\prime}$ E BERGAMASCHI, ${ }^{\prime}$ G M GHIGGERI, ${ }^{2}$ PG RIGHETTI, ${ }^{3}$ M SPAGGIARI, ROSSELLA ALINOVI,' G CANDIANO, ${ }^{2}$ I FRANCHINI'}

From the Institute of Clinical Medicine and Nephrology, ${ }^{1}$ Section of Occupational Medicine, University of Parma, Parma; Department of Nephrology, ${ }^{2}$ Hospital of Lavagna, Genoa; and Department of Biomedical Sciences and Technologies, ${ }^{3}$ University of Milan, Milan, Italy

A reduced ability of red blood cells $(\mathrm{RBC})$ to bind the cationic dye alcian blue $8 \mathrm{GX}(\mathrm{AB})$ was proposed as an indirect marker of glomerular loss of fixed polyanions in minimal change nephrotic syndrome and glomerulosclerosis. ${ }^{12}$ The importance of this test in other glomerulopathies was not confirmed ${ }^{3}$ and its analytical validity was questioned, ${ }^{4}$ the main problem being the incomplete solubilisation of the dye. The latter problem may, however, be overcome by dissolving $\mathrm{AB}$ in $100 \%$ ethanol. ${ }^{5}$ Recently, it has been shown that RBCs from workers exposed to cadmium have a reduced ability to bind $A B{ }^{6}$ Since bound $A B$ was negatively related to albuminuria, it was interpreted as the mirror of a loss in fixed polyanionic charges at the glomerular level. This view was supported by the parallelism between RBC and glomerular basement membranes from experimentally poisoned rats as to their ability to bind AB. We report here findings that substantially confirm those presented by Bernard $e t$ $a l{ }^{6}$ They also, however, cast doubt on the pathophysiological meaning of this test.

\section{Materials and methods}

In a small series of 10 subjects with heavy past exposure to cadmium and in 24 control subjects we examined the urinary excretion of albumin, retinol binding protein (RBP), and brush border antigens by enzyme linked immunosorbent assays. ${ }^{7-9}$ The urinary excretion of cadmium was measured by flameless atomic absorption spectroscopy (Perkin-Elmer, model 3030 Zeeman) and was taken as a measure of cadmium body burden. Urinary concentrations were normalised to $1 \mathrm{~g}$ of creatinine.

\section{Results and discussion}

Albuminuria, urinary RBP, and BBA were signifi- cantly higher in those exposed to cadmium compared $\overrightarrow{0}$ with control subjects (table). Thus our results confirm the previous observations of Bernard et al suggesting a decreased ability of RBC from workers exposed to cadmium to bind $\mathrm{AB}$, such a difference being clearly shown by visual inspection of the figure. ${ }^{6}$ The amount of $\mathrm{AB}$ bound to $\mathrm{RBC}$, however, was correlated not only with albuminuria and cadmiumuria $(r=-0.73$ and -0.62 , respectively; $p<0.05$ ) but also with low molecular weight proteinuria, as measured by urinary $\operatorname{RBP}(r=-0.72 ; p=0.02)$. No relation was found between AB binding to RBCs and the urinary excretion of brush border antigens. The negative correlations of $A B$ binding to $R B C s$ with urinary $R B P$ (uRBP) and cadmium - which in urine also is mainly bound to the low molecular weight protein metallothionein-suggest that $\mathrm{AB}$ binding to $\mathrm{RBC}$ may mirror not only glomerular but also tubular dysfunction. Such a hypothesis would not be consistent with the lack of correlation with the urinary excretion of brush border antigens. Nevertheless, the latter reflects microtissue damage, which does not necessarily parallel tubular dysfunction in subjects with past exposure to cadmium. As a result, AB binding to RBCs seems to show cadmium induced abnormalities which are not confined within the vascular compartment or are not simply related to glycosaminoglycan

Mean values of $C d-U$, albumin, retinol binding protein, and bound alcian blue in workers occupationally exposed to cadmium and in a control group. All values from the exposed o group are significantly higher than in controls $(p<0.01)$

\begin{tabular}{|c|c|c|c|c|}
\hline \multirow[b]{2}{*}{ Variable } & \multicolumn{2}{|c|}{ Exposed workers } & \multicolumn{2}{|c|}{ Controls } \\
\hline & $G M$ & $G S D$ & $G M$ & $G S D$ \\
\hline $\begin{array}{l}\text { Cd-U ( } \mu \mathrm{g} / \mathrm{g} \text { creat) } \\
\text { Albuminuria (mg/g creat) } \\
\text { RBP-U }(\mu \mathrm{g} / \mathrm{g} \text { creat) } \\
\text { BBA (U/g creat) } \\
\text { Bound AB }\end{array}$ & $\begin{array}{r}7 \cdot 77 \\
11 \cdot 21 \\
72 \cdot 78 \\
6 \cdot 52\end{array}$ & $\begin{array}{l}1.87 \\
5.79 \\
6.11 \\
0.51\end{array}$ & $\begin{array}{r}0.38 \\
5 \cdot 34 \\
45 \cdot 21 \\
3.08\end{array}$ & $\begin{array}{l}1.47 \\
1.76 \\
2.64 \\
1.87\end{array}$ \\
\hline (ng/106 RBC) & $48 \cdot 01$ & 1.96 & $128 \cdot 33$ & $1 \cdot 56$ \\
\hline
\end{tabular}




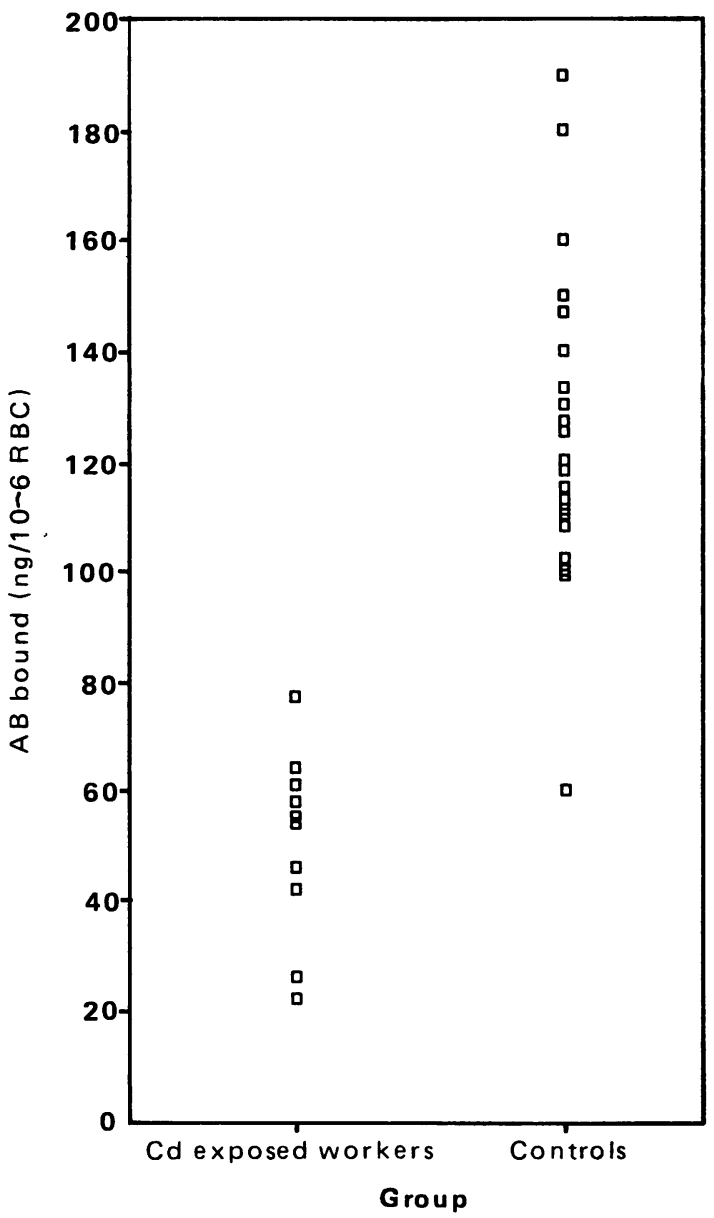

Distribution of individual values of $A B$ binding to $R B C$ in workers occupationally exposed to cadmium and in a control group simultaneously examined.

content and electronegative charges of RBC surface and glomerular basement membrane. The alternative hypothesis that $\mathrm{uRBP}$ reflects changes in glomerular permeability rather than tubular dysfunction would be inconsistent with several papers supporting its validity as a marker of tubular damage. ${ }^{7}$

Further experiments were thus aimed at evaluating whether $\mathrm{AB}$ binding to RBCs actually measures electronegative charges or something else on the RBC membrane. An extensive study of the behaviour of $A B$ in different solvents and in the presence of membraneous and cytoplasmic proteins has been reported elsewhere. ${ }^{10}$ In summary, such experiments point to hydrophobic interactions, with little evidence of any ionic binding.

In separate experiments we also investigated the effects of reducing agents on the RBC-AB binding assay. In the absence of any appreciable precipitation, they enhanced $\mathrm{AB}$ binding in a dose dependent manner. For instance, when RBCs were coincubated with $1 \mathrm{mmol}$ GSH and $\mathrm{AB}$, the binding of the dye increased by $100 \%$. Interestingly, no changes were seen in $A B$ binding when RBCs were preincubated with GSH, suggesting that the enhanced reactivity of $A B$ by reducing agents is due to changes in the dye rather than in membrane charges. In fact, GSH may only reduce the cationic properties of the dye, which could increase its hydrophobic interactions.

The possible target selectivity of AB still remains a tempting hypothesis open to question. In fact, the above experiments lead to the conclusion that the $\mathrm{AB}$ actually measures something on RBC membranes, but certainly something other than electronegative charges. It could be used to probe hydrophobic patches on such surfaces, among which phospholipids such as sphingomyelin are good candidates. ${ }^{10}$

In summary, AB binding assay may be a good marker of some generalised membrane disorders, which are detectable not only among workers chronically exposed to cadmium but also in other clinical conditions. Such membrane disorders, however, may be represented by changes in the hydrophobic domains of the membrane rather than in its sialic acid residues.

\section{References}

1 Levin M, Smith C, Walter MSD, et al. Steroid responsive nephrotic syndrome: a generalised disorder of membrane negative charge. Lancet 1985;ii:239-42.

2 Boulton-Jones JM, McWilliams G, Chandrachud L. Variation in charge on red cells of patients with various glomerulopathies. Lancet 1986;ii:186-8.

3 Feehally J, Samanta A, Kinghorn H, et al. Red-cell surface charge in glomerular disease. Lancet 1986;ii:635.

4 Sewell RF, Brenchley PEC. Red-cell surface charge in glomerular disease. Lancet 1986;ii:635-6.

5 van der Winkel JGJ, Wetzels JFM, van Duijnhoven JLP, et al. Red blood cell surface charge and alcian blue binding. Nephrol Dial Transplant 1987;2:280-1.

6 Bernard AM, Ouled Amor A, Lauwerys RR. Decrease of erythrocyte and glomerular membrane negative charges in chronic cadmium poisoning. Br J Ind Med 1988;45:112-5.

7 Lucertini S, Mutti A, Valcavi P, Franchini I. Enzyme-linked immunosorbent assay of retinol-binding protein in serum and urine. Clin Chem 1984;30:149-51.

8 Valcavi P, Lucertini S, Mutti A, Chezzi C. Urinary albumin. In: Bergmeyer HU, ed. Methods of enzymatic analysis. Vol IX. Weinheim: VCH, 1986:54-63.

9 Mutti A, Lucertini S, Valcavi PP, et al. Urinary excretion of brushborder antigen revealed by monoclonal antibodies: early indicator of toxic nephropathy. Lancet 1985;ii:914-7.

10 Ghiggeri GM, Candiano G, Ginevri F, et al. Hydrophobic interaction of alcian blue with soluble and erythrocyte membrane proteins. J Cromatogr 1988;452:347-57. 